\title{
Dimensões de um intelectual crítico
}

Roberto Goto

editor executivo

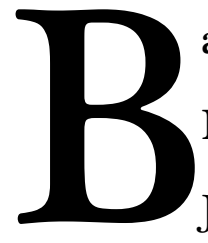

astante conhecido pelos que têm na Teoria Crítica e na Escola de Frankfurt, em geral, e no pensamento de Jürgen Habermas, em especial, o objeto de suas pesquisas e o terreno do labor acadêmico, Pedro Goergen, em suas contribuições para a análise e a discussão da extensa e complexa gama de relações e interações que caracterizam e medeiam o espaço entre Filosofia e Educação, tem exercido um papel que vai muito além da interpretação e da divulgação dessa corrente de pensamento. Antes de tomá-la e desenvolvê-la na condição de "referencial teórico" (na qual, não raramente, costumam se deter e se esgotar, nos limites da academia, as lides do docentepesquisador), sua (pre)ocupação de intelectual crítico a estende por toda a contemporaneidade, que ele perscruta ao mesmo tempo em que a abraça, participando e comprometendo-se: ética, política e educação não são apenas, em seu caso, campos para o exercício e a exploração do trabalho intelectual, mas aspectos que assumem o primeiro plano do mundo presente, e nos quais se projetam e se revelam seus problemas mais cruciais - aqueles que, por isso, exigem e merecem o exame crítico (tão distanciado e racional 
quanto participativo, comprometido com certos valores e ideais) que a visada filosófica propicia.

A amplitude desse horizonte, cultivada coerentemente em consonância com as notas fundamentais da teoria - à qual são inerentes tanto a atitude crítica quanto o compromisso ético, implicando um traço educativo, assim como um travo de inconformismo - mais que justifica a reedição, na forma do dossiê ora apresentado, de textos originalmente publicados no livro Teoria Crítica, Filosofia e Educação: homenagem a Pedro Goergen, organizado por Eldon Mühl, Antonio S. Zuin e Luiz Roberto Gomes (Passo Fundo: Edupf; Maringá: Eduem, 2014). Republicá-los no presente número de Filosofia e Educação significa justamente oferecer a um público mais amplo a oportunidade de tomar contato com uma imagem igualmente ampliada desse intelectual crítico - ampliada não no sentido de hipertrofiar sua parte mais difundida, mas de revelar e dar a conhecer as menos notórias, conferindo-lhes o devido e merecido relevo.

Há que se fazer jus, portanto, à riqueza prismática da figura e da atuação desse intelectual, prestando atenção para a, digamos, tridimensionalidade que lhes é conatural, condição para que elas sejam conhecidas e compreendidas em profundidade, em toda a extensão que se põe entre a discussão e a reflexão filosóficas, de um lado, e as realidades, crises, paixões e angústias da educação, de 
outro. Ao procurar ampliar o alcance e a repercussão das vozes que se pronunciam na obra citada, esta revista espera contemplar o leitor com a possibilidade de mirar e examinar essa imagem mais complexa e múltipla - olhar e exame que devem acabar sendo, eles próprios, também múltiplos e complexos.

Buscando refletir e dar conta da aludida tridimensionalidade, a expressão que dá título a este número compreende e ressoa planos que podem ser apresentados na seguinte ordem, a qual não traduz, em nenhum momento, qualquer intenção hierarquizante. Dum ponto de vista mais diretamente filosófico, ela significa o mundo segundo Pedro Goergen; trata-se de sua Weltanschauung, de como ele vê e enfrenta a realidade contemporânea e suas crises, ao tomá-la(s) como alvo e objeto de um trabalho investigativo, reflexivo e discursivo estruturado com fundamento nas categorias da Teoria Crítica, dentre elas destacando-se as hauridas no pensamento de Habermas.

Numa perspectiva mais pessoal, empírica, a expressão refere o mundo rente à pele, em ambos os sentidos - dentro e fora das fronteiras demarcadas pela epiderme. É o próprio ser e o modo de ser do intelectual, o mundo Pedro Goergen - ele sendo (todo) um mundo, que se deixa adivinhar e apanhar nos textos. Para isso não é necessário explorar entrelinhas nem garimpar subtextos; basta 
captar o tom, sentir justamente a pele do discurso, apalpar suas pulsações, conferir sua forma, abrir os ouvidos para seu jeito de falar.

A terceira e não menos importante dimensão é a da praxis, com seus múltiplos e complexos aspectos e reflexos - o teórico, o ético, o político, entre eles. É o mundo das relações de Pedro Goergen, do seu diálogo com o(s) outro(s), sejam pesquisadores, sejam discípulos, sejam oponentes, adversários, discordantes. Dele emanam e nele se ressaltam imagens de sua maestria na arte de dialogar, numa observância coerente dos pressupostos da teoria filosófica assumida: por elas, vê-se e/ou recorda-se o professor ou interlocutor que espera e escuta os pontos de vista e argumentos alheios, que os estimula e/ou os tempera com intervenções oportunas, pertinentes, criativas e irônicas, conforme o caso quase nunca, porém, de forma previsível, na medida em que se trata de alguém que desenvolveu uma segunda arte, no âmbito da dialógica. Trata-se justamente da arte de intervir no debate de modo a que se construam argumentos pessoais e coletivos, como que imiscuindo-se nos interstícios dos discursos alheios, neles antevendo e deles retirando pensamentos de que, no momento, o próprio autor ainda não se deu conta. Se cabe classificar essa arte 
como "construtivista", convém acrescentar-lhe, ao menos como apêndice, o humor, na forma de um grano salis socrático ${ }^{1}$.

Como o leitor pode atestar e experimentar, cada uma dessas dimensões se faz presente nos escritos reunidos no dossiê, em maior ou menor medida - dessa variação dependendo o sabor específico de cada um. Mesmo os que parecem não versar direta e explicitamente sobre esse mundo (sobre sua letra, em suma) trazem e exprimem, já na eleição de seus temas, assim como no modo de tratá-los, o espírito ou, no mínimo, o sentimento desse mundo: um mundo, afinal, bastante sociável, dado e aberto ao outro e ao comum, na medida mesma em que capaz ou, pelo menos, disposto a compreender o singular, o único ou o exclusivo assim como avesso a todo e qualquer solipsismo, que ele lamenta e refuta, a par do vulgar e abusivo individualismo e do arraigado e insensível hedonismo, no próprio movimento de crítica à sociedade contemporânea. Em face dessa sociedade acrítica, submissa e cegamente atrelada e devotada ao mercado, é ele o outro - o outro

1 Integrantes da turma que Pedro Goergen coordenava como responsável pela disciplina Seminários Avançados de Filosofia da Educação, na Faculdade de Educação da Unicamp, nos idos de 1998, devem lembrar-se: durante a discussão de um tema, que derivou para a questão da quase ausência de mulheres na galeria de compositores, alguém mencionou o nome de Chiquinha Gonzaga, aliás muito citado na época. Pedro Goergen interveio perguntando: “Quem é Chiquinha Gonzaga?” Entre uma e outra tentativa de resposta a essa pergunta que todos tinham como retórica, tomada portanto como uma cobrança do mestre para que os alunos explicitassem o saber a respeito do que falavam, ele voltou a intervir, explicando: "Estou perguntando porque não sei quem é Chiquinha Gonzaga..."

Filosofia e Educação [RFE] - Volume 8, Número 2 - Campinas, SP Junho-Setembro de 2016 - ISSN 1984-9605 - p. 1-6 
mundo, o avesso ou o negativo que põe em evidência suas fissuras e carências.

Se a (con)vocação desse mundo ao comum não pode ser associada ou referida à acepção arendtiana, pode sê-lo ao sentido mais comezinho das expectativas e perspectivas filosóficas e educacionais, no contexto das quais se constitui como um sentimento compartilhado ou compartilhável por semelhantes e diferentes - e mesmo divergentes. É porventura o que se nota pelo confronto entre os textos do dossiê e os que vão publicados nas outras seções deste número, nos quais se manifestam anseios e (pre)ocupações que parecem emanar de um fundo comum, como se diferentes e dissonantes vozes, que soam segundo suas respectivas claves teóricas, contassem com um mesmo baixocontínuo para sustentá-las: uma corrente coletiva subterrânea retomando a expressão adorniana - que serpeia através e apesar de relativismos e relativizações e cuja existência talvez seja motivo suficiente para sondar e cevar a esperança como fator e princípio. 